\title{
The Effect of Self-Evacuation Drill on The Preparedness Level of Children with Disabilities in Facing Tornado Disaster
}

\author{
Serly Sani Mahoklory ${ }^{\circledR}{ }^{\bowtie}$, Ferdinandus Suban Hoda ${ }^{1}$ \\ Ners, Sekolah Tinggi Ilmu Kesehatan Maranatha Kupang, Indonesia(1) \\ DOI: $\underline{10.31004 / \text { obsesi.v6i3.1636 }}$
}

\begin{abstract}
Many of these casualties are high risk groups, one of which is children with disabilities. This study aimed to investigate the preparedness level of children with disabilities in facing tornado before and after participating in the self-evacuation drills. This is a quasi-experimental study with one group pre- and post- test with control group design. Results indicated that the preparedness level of children with disabilities in intervention group before intervention was 46.47 ( \pm 13.101$)$, while in control group was $43.13( \pm 13.101)$. After intervention, the preparedness level in intervention group increased significantly compared to control group $(p=0.000)$ and the mean of preparedness level in intervention group rose to $51.63( \pm 10.516)$ while control group did not record any increase with a mean of $41.20( \pm 12.288)$. These findings suggest that a learning method through a self-evacuation drill with audio-visual technique is more effective to improve the understanding of preparedness to face tornado among children with disabilities.
\end{abstract}

Kata Kunci: disaster; tornado, preparedness; children with disabilities

\begin{abstract}
Abstrak
Dampak dari bencana angina putting beliung yang mengakibatkan banyak korban jiwa adalah kelompok rentan, diantaranya anak penyandang disabilitas.Tujuan dari penelitian ini adalah untuk mengetahui kesiapsiagaan anak penyandang disabilitas dalam menghadapi bencana angin putting beliung sebelum dan sesudah diberikan latihan evakuasi mandiri. Metode penelitian yang digunakan adalah Quasi experimental dengan rancangan one group pre andpost test with control group design". Hasil penelitian tingkat kesiapsiaagan anak penyandang disabilitas pada kelompok perlakuan sebelum intervensi sebesar 46,47 $( \pm 13,101)$, sedangkan tingkat kesiapsiagaan anak disabilitas pada kelompok kontrol sebesar $43,13( \pm 13,101)$. Setelah perlakuan skor kesiapsiagaan pada kelompok perlakuan meningkat signifikan dibandingkan kelompok kontrol $(\mathrm{p}=0,000)$ dan rerata skor kesiapsiagaan kelompok perlakuan meningkat menjadi 51,63 $( \pm 10,516)$ sedangkan kelompok kontrol tidak mengalami peningkatan 41,20 $( \pm 12,288)$. Hal ini menunjukkan bahwa metode pembelajaran melalui latihan evakuasi mandiri dengan teknik audio visual lebih efektif dalam meningkatkan pemahaman anak disabilitas terhadap kesiapsiagaan saat terjadi bencana angin putting beliung.
\end{abstract}

Kata Kunci : bencana. angin putting beliung; kesiapsiagaan; anak penyandang disabilitas

Copyright (c) 2021 Serly Sani Mahoklory, Ferdinandus Suban Hoda

$\triangle$ Corresponding author :

Email Address : sani.mahoklory04@gmail.com (Kupang, Indonesia)

Received 12 May 2021, Accepted 15 October 2021, Published 22 October 2021 


\section{INTRODUCTION}

Children with behavioural, mental, physical and sensory disorders are a vulnerable group to natural disaster. The prevalence of people with disabilities in NTT province is the second highest in Indonesia with 19.2\% (Survey, n.d.). Meanwhile in 2018, Basic Health Survey reported that the proportion of people with severe disabilities and totally dependent was $3.3 \%$ in people aged $5-17$ years, $22 \%$ in people aged $17-59$ years, and $2.6 \%$ in people aged $\geq$ years (Survey, n.d.) The high prevalence of disabilities in NTT may increase the risk of casualties during natural disaster.

Natural disaster are unpredicted and uncontrolled events that usually resulted in casualties and damaged ecosystem. One of the disasters that often happen in NTT in the last two years is tornado. Based on disaster information data from The Indonesian National Board for Disaster Management (BNBP) and Geoportal Kebencanaan Indonesia, in NTT province there were 14 incidents of tornado in 2018, 8 incidents of tornado in 2019, and 12 incidents in 2020. These data indicated that the incidents of tornado tend to increase each year (Badan Nasional Penanggulangan Bencana, 2012);(EM-DAT, 2004).

The threat of tornado also draws special attention to children with disabilities. Due to the fact that children with disabilities are usually unable to develop a plan of preparedness, the lack of understanding with the condition of their surroundings and the absence of readiness to access help to save themselves independently during the incidence of tornado. Thus, increasing their understanding to the preparedness is the main key to their survival (Setyorini \& A., n.d.); (Rooks \& Garrett, 2016).

Preparedness is a series of activities carried out to anticipate disaster through organizing and taking the appropriate and efficient steps. One of the recommended steps by BNBP to reduce casualties is self-evacuation drills (LPEM FEB UI, 2017). Self-evacuation drill is an act of self-help when natural disaster occurs. The steps for self-evacuation exercises for children with disabilities; (1) demonstrate how to close doors and windows (2) demonstrate how to avoid glass windows, large cabinets, tall trees, billboards and other objects that can fall on children, (3) demonstrate a squatting position with both hands covering the head, (4) demonstrate how to give a message to the rescuer that you are trapped in the room. These steps are carried out with the addition of audio-visual and also sign language guidelines carried out by linguists.

This is important as during disaster, the survival of children with disabilities lies with their parents thus increasing casualties. With self-evacuation drills, children with disabilities may obtain readiness and preparedness in facing natural disaster without depending on other people. Giving stimulus in the form of audio visual and motoric can encourage understanding of children with disabilities in recognizing how to self-evacuate and readiness in the event of a natural disaster (Setyaningrum \& Setyorini, 2012)(Setyorini \& A., n.d.)(Setyorini \& A., n.d.).

Many studies have been conducted by experts on the level of preparedness in the event of a natural disaster, but very few have investigated the preparedness of vulnerable groups, especially children aged 6 to 12 years with disabilities. this is evidenced by the few references found in the homebase of international journals. while the riskesdas data shows that one of the contributors to the high death toll during natural disasters is people with mental and physical disabilities.This study aimed to investigate the effectivity of self-evacuation drill to the preparedness of children with disabilities in the event of a natural disaster measured based on readiness index which was categorised according to the type of the disability.

\section{METHODS}

This is a quasi-experimental study with one group pre- and post-test with control group design. Intervention group received self-evacuation drill while control group received direction and explanation of preparedness in the event of natural disaster. This study involved 60 students with disabilities in Pembina Primary School Kupang aged 7 to 15 years who were 
divided into 2, namely 30 children for the intervention group and 30 children for the control group.

The data collection process begins with permission to go to school and data collection of names and addresses of students. Furthermore, the researcher and the teacher door to door to the students' homes to get parental approval as research respondents. Teacher assistance in determining the research sample is very important, because the level of parental trust in teachers is very high, so parents are willing to include their children in this study. Research data collection techniques using purposive sampling. This data collection technique was chosen because not all students with multiple disabilities, physical disabilities, and autism can participate in the research process. this is due to the limitations of two or more limbs so that they cannot carry out independent evacuation exercises.

This study implemented self-evacuation drill steps that had been audio and visually modified to fit the condition of children with disabilities. Such modifications are needed because Pembina Extraordinary Primary School already has a disaster management and disaster warning book, even though it has not been taught and unfit for children with disabilities. And the process of filling the questionnaire respondents S3 with elementary school level researchers read out one by one the question contained in the questionnaire and invite students to answer according to the question that was read.

The indicators used in this study as seen on Table 1, each parameter will be calculated based on preparedness index with the formula 1, and preparedness index scoring is formulated as seen on Table 2.

Table 1. Indicators of Research

\begin{tabular}{llllll}
\hline No. & \multicolumn{1}{c}{ Variable } & \multicolumn{4}{c}{ Instrument } \\
\hline 1. & Preparedness & Knowledge and & Plan of & Disaster & Mobilisation \\
& (Parameters & behaviour (KAP) $)$ & preparedness & warning & of resources \\
& from LIPI- & 20 questions. & (EP) $: 2$ & (WS) $: 1$ & (RMC) $: 1$ \\
& UNESCO) & Indexs $: 0,83$ & questions. & questions. & questions. \\
& & & Indexs $: 0,08$ & Index $: 0,04$ & Index $: 0,04$ \\
\hline 2. & Self & Disaster preparedness training guidelines (4 self evacuating steps) & \\
& Evacuation & & & \\
& Drill & & & \\
\hline
\end{tabular}

$$
\text { preparedness index }=\frac{\text { real total of parameter } \times 100 \%}{\text { maximum score of parameter }}
$$

Formula 1. Preparedness Index

Table 2. Preparedness Index Score Categories

\begin{tabular}{ccc}
\hline No & Index Score & Category \\
\hline 1 & $80-100$ & Very Well Prepared \\
2 & $65-79$ & Prepared \\
3 & $55-64$ & Almost Prepared \\
4 & $40-54$ & Less Prepared \\
5 & $0-39$ & Unprepared \\
\hline
\end{tabular}

The data were analyzed using the calculation of the index value of the maximum score in which each question has a value of one.the index value is in the range of 0-100 so the higher the index value the higher the level of preparedness. Then the analysis comprised of univariate and bivariate analysis named Mann-Whitney $U$ test using a software. 
DOI: $10.31004 /$ obsesi.v6i3.1636

Table 3. characteristics of Participants based on characteristics of participants based on Gender, Grade, and type of disability in Pembina Primary School Kupang Gender, Grade, and Type of Disability in Pembina Primary School Kupang

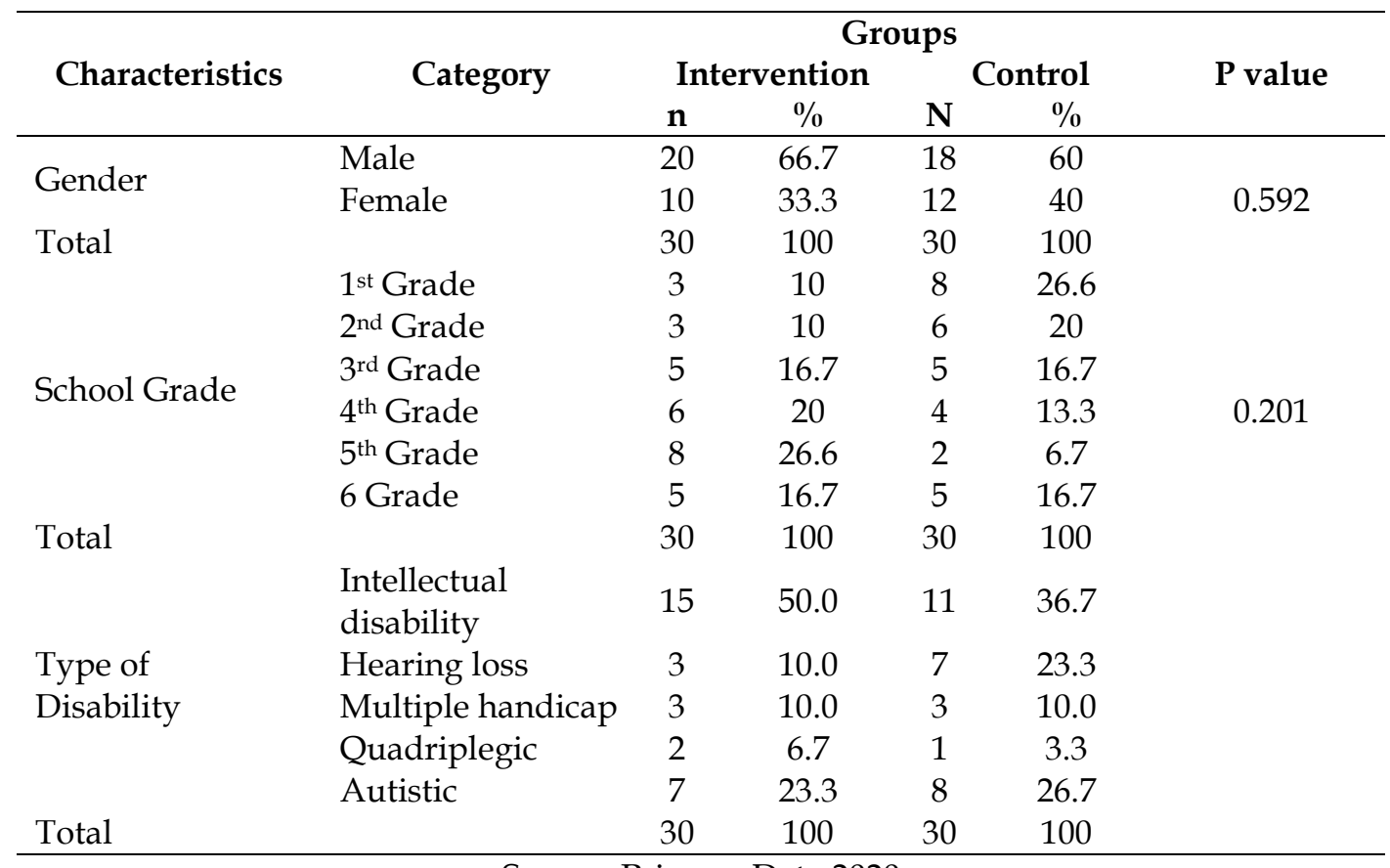

Source: Primary Data 2020

Table 3 shows that $60 \%$ of the participants which were divided into 30 participants in intervention group and 30 participants in control group had no difference in characteristics, gender, and grade. Most of the participants are male and second grader in primary school. From a total of 60 participants in both groups, most of the intervention group (15 participants, $50 \%)$ and 11 participants (36.7\%) in control group have intellectual disability.

Table 4. Characteristics of Participants based on Age in Pembina Primary School Kupang

\begin{tabular}{lllccccc}
\hline Characteristics & Groups & N & Mean & SD & Min & Max & p-value \\
\hline \multirow{2}{*}{ Age } & Intervention & 30 & 11.40 & 2.222 & 7 & 15 & 0.441 \\
& Control & 30 & 10.93 & 2.149 & 7 & 15 & \\
\hline Total & 60 \\
\hline \multicolumn{7}{c}{ Source: Primary Data 2020 }
\end{tabular}

Table 4 showed that from a total of 60 participants, the mean age of the participants was 11 years old in intervention group and 10 years old in control group.

\section{RESULTS AND DISCUSSION}

These results suggest that learning method through self-evacuation drill with audio visual technique is more effective in improving the understanding of preparedness among children with disabilities during the occurrence of a tornado. It is supported by an association result on each of the variables used as indicators of:

\section{Preparedness Level of Children with Disabilities Who Participated in Self-Evacuation Drill}

Based onresearch results preparedness level of children with disabilities who participated in self evacuation drill showed a significant increase. This is evidenced by the results of the pre-test and post-test of the respondents in the table 5 : 
Table 5. Distribution of Preparedness Level of Children with Disabilities Who Participated in SelfEvacuation Drill

\begin{tabular}{|c|c|c|c|c|c|}
\hline \multirow{2}{*}{ Variables } & \multirow{2}{*}{$\begin{array}{l}\text { Category } \\
\text { Intervention }\end{array}$} & \multicolumn{2}{|c|}{ Pre-test } & \multicolumn{2}{|c|}{ Post-test } \\
\hline & & $\mathbf{F}$ & $\%$ & $f$ & $\%$ \\
\hline \multirow{13}{*}{ Preparedness } & Very well prepared $(80-100)$ & 0 & 0 & 0 & 0 \\
\hline & Prepared $(65-79)$ & 0 & 0 & 0 & 0 \\
\hline & Almost prepared $(55-64)$ & 10 & 33 & 14 & 47 \\
\hline & Less prepared $(40-54)$ & 13 & 43 & 13 & 43 \\
\hline & Unprepared $(0-39)$ & 7 & 23 & 3 & 10 \\
\hline & Total & 30 & 100 & 30 & 100 \\
\hline & Control & & & 30 & 100 \\
\hline & Very well prepared $(80-100)$ & 0 & 0 & 0 & 0 \\
\hline & prepared $(65-79)$ & 0 & 0 & 0 & 0 \\
\hline & Almost prepared $(55-64)$ & 8 & 27 & 5 & 17 \\
\hline & Less prepared $(40-54)$ & 14 & 47 & 11 & 37 \\
\hline & Unprepared $(0-39)$ & 8 & 27 & 14 & 47 \\
\hline & Total & 30 & $100 \%$ & 30 & $100 \%$ \\
\hline
\end{tabular}

Source: Primary Data 2020

Based on research resultsintervention of giving self-evacuation drill can improve the preparedness level of children with disabilities. Participants with preparedness level of Almost Prepared during pre-test (33\%) increased to 47\% during post-test. And those with Unrepared level during pre-test (23\%) lessen (to 10\%) during post-test. Meanwhile, in control group, participants with preparedness level of Unprepared during pre-test (27\%) rose in posttest $(47 \%)$. From a total of 60 participants whose preparedness level have been measured, there were no participants with preparedness level of Very Well Prepared and Prepared.

This is due to the improvement of understanding of children with disabilities begins with interactive and applicable learning methods. A review study on the education of children with disabilities emphasised that face-to-face learning methods by utilising alternative and augmentative communication technologies is widely known can improve the cognitive and social interactions of children with disabilities (Guillomía et al., 2021). Therefore, an effective method to develop preparedness for children with disabilities in dealing with natural disasters is to practice self-evacuation; a short demonstration using audio-visual help emphasise the self-evacuation steps. A similar finding was observed by Nasrullah et al. (2021) in a study about the Development of Comic Media to improve understanding of flood disaster preparedness in children. The study found that using the "Aku Pintar Siaga" flood disaster comic effectively increased understanding of flood disaster preparedness for children aged 78 years (Nasrullah et al., 2021).

The development of learning methods in self-evacuation exercises aims to improve children's understanding and motor skills about preparedness to cope with hurricane disasters. The implementation of the self-evacuation exercise is based on a preliminary study and literature study on disaster by modifying the technical implementation to accommodate children with disabilities (Rahiem \& Widiastuti, 2020). The knowledge of disaster preparedness should be introduced as early as possible to children with disabilities because they are a vulnerable group that must receive protection against disaster. The special needs school teachers support this recommendation that applying the self-evacuation exercise learning method is one of the appropriate learning strategies because it is interesting and easy to understand. Furthermore, an independent evacuation exercise consisting of four steps of disaster evacuation involving children as learning subjects makes the learning material easy to remember and re-practice. Hopefully, this practice can increase children's confidence and readiness to cope with disaster (Maciver et al., 2019) 
DOI: 10.31004/obsesi.v6i3.1636

\section{Preparedness Level of Children with Disabilities Based on The Type of Disability}

Based on research results, the type of mentally retarded disability has a better level of preparedness than other types of disability. this can be seen in the results of the study in table 6:

Table 6. Distribution of Preparedness Level of Children with Disabilities based on The Type of Disability

\begin{tabular}{|c|c|c|c|c|c|c|c|c|c|c|}
\hline \multirow{2}{*}{ Preparedness Level } & \multicolumn{2}{|c|}{$\begin{array}{c}\text { Intellectual } \\
\text { Disability }\end{array}$} & \multicolumn{2}{|c|}{$\begin{array}{l}\text { Hearing } \\
\text { Loss }\end{array}$} & \multicolumn{2}{|c|}{$\begin{array}{c}\text { Multiple } \\
\text { Handicaps }\end{array}$} & \multicolumn{2}{|c|}{ Quadriplegic } & \multicolumn{2}{|c|}{ Autistics } \\
\hline & $\mathrm{F}$ & ро $\%$ & $\mathrm{~F}$ & $\%$ & $\mathrm{~F}$ & $\%$ & $\mathrm{~F}$ & $\%$ & $\mathrm{~F}$ & $\%$ \\
\hline Very well prepared $(80-100)$ & 0 & 0 & 0 & 0 & 0 & 0 & 0 & 0 & 0 & 0 \\
\hline Prepared $(65-79)$ & 0 & 0 & 0 & 0 & 0 & 0 & 0 & 0 & 0 & 0 \\
\hline Almost prepared $(55-64)$ & 18 & 69 & 0 & 0 & 0 & 0 & 0 & 0 & 0 & 0 \\
\hline Less prepared $(40-54)$ & 6 & 23 & 6 & 60 & 4 & 67 & 2 & 67 & 9 & 60 \\
\hline Unprepared $(0-39)$ & 2 & 8 & 4 & 40 & 2 & 33 & 1 & 33 & 6 & 40 \\
\hline Total & 26 & 100 & 10 & 100 & 6 & 100 & 3 & 100 & 15 & 100 \\
\hline
\end{tabular}

Source: Primary Data 2020

The results of the study that divided children with disabilities based on the type of disability showed that the preparedness of most children was not ready; mental retardation (40-54) 16 children, deaf (0-39) 6 children, multiple handicaps (0-39) 6 children, physically disabled/quadriplegia (0-39) 3 children, and autism (0-39) 11 children.

Individual and group characteristics of different situations will affect the capacity to prepare for, respond to and recover from natural disasters (Men \& Disaster, 2016). Children are one of the most vulnerable groups to harm. The level of vulnerability of each child depends on age, gender, class, environment, intellectual level, and physical ability. The highest vulnerability is in children with physical, intellectual, and sensory disabilities or limitations (Aryankhesal et al., 2018). This study showed that most children with disabilities at Pembina Kupang Elementary School experienced mental retardation $(n=26)$. Therefore, the alertness of hurricane disasters is important to increase the understanding of children with disabilities on how to protect themselves when a hurricane occurs. During the self-evacuation exercise process, children with mental retardation showed a higher level of preparedness than deaf children, quadriplegic, multiple handicapped and autistic. This finding shows that children with mental retardation have a better understanding than other types of disabilities (Maciver et al., 2019).

The presence of physical limitations experienced by children who are deaf, quadriplegic and children with multiple handicaps, make it difficult for them to follow each step in the self-evacuation exercise, so they need the help of others in evacuating themselves (de la Cruz \& Ramírez, 2020). I Meanwhile, autistic children with interaction and communication disorders require a longer time in the process of introduction, self-approach and implementation of self-evacuation. The ability of children with disabilities to understand preparedness and implementing independent evacuation interventions in the event of a disaster differs from one another. Low intellectual ability and weakness in thinking abstract things cause the achievement of learning objectives that are less than optimal. Independent evacuation interventions for children with special needs require a relatively long time. Therefore, support from teachers, parents, families and health workers is needed to achieve preparedness in the ready category (Guillomía et al., 2021).

\section{Preparedness Level Between Intervention and Control Groups}

Table 7 proclaimed the mean of preparedness level of children with disabilities in intervention group before intervention was $46.47( \pm 13.101)$, on the other hand, the preparedness level of control group was 43.13 ( \pm 13.101$)$. Results of further analysis with Mann- 
Whitney $\mathrm{U}$ test showed no significant different of preparedness score between intervention and control groups $(\mathrm{p}=0.347)$ before participating in self-evacuation drill. After intervention, the preparedness score in intervention group increased significantly compared to control group $(p=0.000)$ and the mean score of preparedness in intervention group rose to 51.63 $( \pm 10.516)$, while control group did not record any increase with a mean of $41.20( \pm 12.288)$.

Table 7. Mean Difference Analysis of Preparedness Level between Intervention and Control Groups

\begin{tabular}{clcccc}
\hline Preparedness Level & \multicolumn{1}{c}{ Groups } & Mean & SD & Min-Max & p-value \\
\hline \multirow{2}{*}{ Before self-evacuation drill } & Intervention $(\mathrm{n}=30)$ & 46.47 & 13.101 & $18-63$ & 0.347 \\
& Control $(\mathrm{n}=30)$ & 43.13 & 15.804 & $14-61$ & \multirow{2}{*}{ After self-evacuation drill } \\
& Intervention $(\mathrm{n}=30)$ & 51.63 & 10.516 & $20-64$ & 0.000 \\
& Control $(\mathrm{n}=30)$ & 41.20 & 12.288 & $19-59$ & \\
\hline & Source: Primary Data 2020 & & &
\end{tabular}

Children with disabilities mostly spend their time outdoor like in school, playground, and with their friends. For that, they have to know how to respond to a disaster while doing outdoor activities (Edmonds, 2017). Several studies showed that children with disabilities including autistic, hearing loss, quadriplegic and other mental disorders often have difficulty in recognizing signs of danger that happen around them. Also, they often experience stress when they hear emergency alarm during disaster, thus, children with disabilities become vulnerable during natural disaster (Hanreddy \& Östlund, 2020); (Seddighi, 2020).

Based on report conducted by (Edmonds, 2017) in Britain to people with disabilities and autism, a way to resolve differences in thinking ability during emergency situation of people with disabilities was found. The preparedness of people with disabilities and autism need to be focused on two different things. First, it is important to prepare individual learning materials for each condition. Second, during the event of emergency for example natural disaster, resources used during emergency need to be personalised making it simpler and can be utilised by children with disabilities (Widomska et al., 2009), (Pohl et al., 2020). Intellectual, physical, and sensory integration disabilities derived limitations in children's ability to understand information and applying new skills, resulting in dependency on their families. Selection of the appropriate learning method can help children's independence in interacting with peers, adults, space, and objects around them (Seddighi et al., 2020), (Maciver et al., 2019). However, the one-way learning method with the focus on the teacher was unable to improve the understanding of children with disabilities. This event can be seen in a study result where the control group who only received education about disaster preparedness did not increase the level of disaster preparedness. In contrast, the intervention group experienced an increase in preparedness. This finding shows that the learning method through self-evacuation exercises with audio-visual techniques is more effective in increasing the understanding of children with disabilities on preparedness in the hurricane disaster.

\section{CONCLUSION}

The selection of appropriate learning and training methods can affect the achievement of the level of preparedness of children with disabilities in dealing with disasters. For this reason, intellectual, sensory and perceptual abilities can be improved through regular disaster self-evacuation exercises. These findings indicated an increase of preparedness level of children with disabilities who participated in self-evacuation drill. Thus, the self-evacuation drill is highly recommended in disaster management education in Pembina Extraordinary School Kupang. 


\section{ACKNOWLEDGMENTS}

Thanks to the ministry of research, technology and higher education which has provided financial assistance in the implementation of this research.

\section{REFERENCES}

Aryankhesal, A., Pakjouei, S., \& Kamali, M. (2018). Safety Needs of People with Disabilities during Earthquakes. Disaster Medicine and Public Health Preparedness, 12(5), 615-621. https://doi.org/10.1017/dmp.2017.121

Badan Nasional Penanggulangan Bencana. (2012). Buku Saku Tanggap Tangkas Tangguh Menghadapi Bencana. Badan Nasional Penanggulangan Bencana, 62. https://siaga.bnpb.go.id/hkb/po-content/uploads/documents/Buku_Saku10Jan18_FA.pdf

de la Cruz, S. P., \& Ramírez, I. (2020). Parents' perceptions regarding the implementation of a physical therapy stimulation program for children with disabilities in bolivia: A qualitative study. International Journal of Environmental Research and Public Health, 17(17), 1-12. https:// doi.org/10.3390/ijerph17176409

Edmonds, C. O. (2017). Designing Emergency Preparedness Resources for Children with Autism. International Journal of Disability, Development and Education, 64(4), 404419. https:// doi.org/10.1080/1034912X.2016.1264577

EM-DAT. (2004). The International Disaster Database - Centre for Research on the Epidemiology of Disaster. 5650.

Guillomía, M. A., Artigas, J. I., \& Falcó, J. L. (2021). Cognitive accessibility and support in special education. Sensors, 21(14). https://doi.org/10.3390/s21144871

Hanreddy, A., \& Östlund, D. (2020). Alternate curricula as a barrier to inclusive education for students with intellectual disabilities. International Electronic Journal of Elementary Education, 12(3), 235-247. https:// doi.org/10.26822/iejee.2020358217

LPEM FEB UI. (2017). Memetakan Penyandang Disabilitas (PD) di Pasar Tenaga Kerja Indonesia. http://www.oit.org/wcmsp5/groups/public/---asia/---ro-bangkok/--ilo-jakarta/documents/publication/wcms_587668.pdf

Maciver, D., Rutherford, M., Arakelyan, S., Kramer, J. M., Richmond, J., Todorova, L., RomeroAyuso, D., Nakamura-Thomas, H., Velden, M. ten, Finlayson, I., O'Hare, A., \& Forsyth, K. (2019). Participation of children with disabilities in school: A realist systematic review of psychosocial and environmental factors. PLoS ONE, 14(1), 1-22. https://doi.org/10.1371/journal.pone.0210511

Men, M., \& Disaster. (2016). Men, Masculinities and Disaster. In E. Enarson \& B. Pease (Eds.), Men, Masculinities and Disaster. Routledge. https://doi.org/10.4324/9781315678122

Nasrullah, Y., Akbar, Z., \& Supena, A. (2021). Pengembangan Media Komik untuk Meningkatkan Pemahaman Kesiapsiagaan Bencana Banjir pada Anak. Jurnal Obsesi : $\begin{array}{llll}\text { Jurnal Pendidikan Anak Usia Dini, 6(2), 832-843. } & \text {. }\end{array}$ https://doi.org/10.31004/obsesi.v6i2.1540

Pohl, A. L., Crockford, S. K., Blakemore, M., Allison, C., \& Baron-Cohen, S. (2020). A comparative study of autistic and non-autistic women's experience of motherhood. Molecular Autism, 11(1), 1-12. https:/ / doi.org/10.1186/s13229-019-0304-2

Rahiem, M. D. H., \& Widiastuti, F. (2020). Pembelajaran Mitigasi Bencana Alam Gempa Bumi untuk Anak Usia Dini melalui Buku Bacaan Bergambar. Jurnal Obsesi: Jurnal Pendidikan Anak Usia Dini, 5(1), 36. https:// doi.org/10.31004/obsesi.v5i1.519

Rooks, M. G., \& Garrett, W. S. (2016). Gut microbiota, metabolites and host immunity. Nature Reviews Immunology, 16(6), 341-352. https:// doi.org/10.1038/nri.2016.42

Seddighi, H. (2020). Trust in Humanitarian Aid from the Earthquake in 2017 to COVID-19 in Iran: A Policy Analysis. Disaster Medicine and Public Health Preparedness, 14(5), e7e10. https://doi.org/10.1017/dmp.2020.54 
Seddighi, H., Yousefzadeh, S., López López, M., \& Sajjadi, H. (2020). Preparing children for climate-related disasters. In BMJ Paediatrics Open (Vol. 4, Issue 1). https:// doi.org/10.1136/bmjpo-2020-000833

Setyaningrum, N., \& Setyorini, A. (2012). Tingkat Kesiapsiagaan Kepala Keluarga Dalam Menghadapi Bencana Gempa bumi Di Kecamatan Pleret dan Piyungan Kabupaten Bantul. Foreign Affairs, 91(5), 1689-1699.

Setyorini, S. N., \& A. (n.d.). The Level Prepararedness Head Of Family For Facing The Earthquake Disaster Sub District Pleret And Piyungan In Bantul Distric. Foreign Aff, 2012;91(5).

Survey, B. H. (n.d.). Riskesdas Main Result.

Widomska, J., Kostecka-Gugała, A., Latowski, D., Gruszecki, W. I., \& Strzałka, K. (2009). Calorimetric studies of the effect of cis-carotenoids on the thermotropic phase behavior of phosphatidylcholine bilayers. Biophysical Chemistry, 140(1-3), 108-114. https:// doi.org/10.1016/j.bpc.2008.12.002 